\title{
Exploring participants' views on a supported work internship programme for autistic and learning disabled young people
}

Anna Melissa Romualdez, Katie Yirrell, and Anna Remington

Centre for Research in Autism and Education (CRAE), UCL Institute of Education, University College London

Corresponding author: Dr Anna Remington

Centre for Research in Autism and Education (CRAE), UCL Institute of Education, University College London, 55-59 Gordon Square, London WC1H 0NU

a.remington@ucl.ac.uk

$+442079115361$

\section{Author Statements}

All co-authors have reviewed and approved of the manuscript prior to submission.

This manuscript is original work and has not published, in press, or submitted elsewhere.

The authors have no conflicts of interest to report. 


\section{Exploring participants' views on a supported work internship programme for autistic and learning disabled young people}

Running head: Supported internships for learning disabled people

Word count: 5649

Abstract: Individuals with additional needs, such as learning disabilities, face a crisis of unemployment in the United Kingdom. Many of these individuals encounter few adult services in place to address their support needs. Supported work internship programmes are one attempt to address this crisis. One such programme for young people with learning disabilities is the Project SEARCH model. Though a number of research studies have explored the efficacy of the Project SEARCH model, the reported markers of success (e.g. subsequent employment rates) have not taken into account first hand participant experiences. The current study aimed to establish whether participant views were consistent with the previously reported, positive, quantitative measures. We explored the views of seven interns, aged 17-24 years, with various learning difficulties, and three job coaches who were involved in the programme from September 2017 to June 2018. Semi-structured interviews were conducted and analysed using thematic analysis. Participants revealed meaningful experiences for those involved, positive self-development, and renewed aspirations for the future. The value of a strong and consistent support network involving family members, job coaches, co-workers, and supervisors was highlighted. The study also found on-going challenges associated with the scheme. These centred on concerns that interns' abilities were being underestimated, the impact of a reduction/withdrawal of support at the conclusion of the programme, and the barriers to finding subsequent competitive employment for interns. The research highlights the value of eliciting participant voice within research, and discusses how the findings can be used to further develop supported work internship programmes. 
Key words: Supported employment, supported work internship, Project SEARCH, Autism Spectrum Conditions, learning disability

\section{Introduction}

Unemployment is high among those with developmental and learning conditions such as autism, Down's Syndrome, language delays, and Specific Language Impairment (UK Parliament Report, 2018). In fact, the most recent report from the UK Parliament (2018) found that only $49 \%$ of disabled people age 16-64 were in some form of employment, compared to $81 \%$ of non-disabled people. For those with a learning condition, the employment rate is far lower still: fewer than $20 \%$ are in work (UK Parliament, 2018). This is in spite of the fact that neurodiversity in the workplace, that is, employing people with conditions that mean they process input from the world differently (Mottron, 2011), has been shown to be an advantage for businesses and companies who hire these individuals (Austin \& Pisano, 2017). The importance of employment for autistic and learning disabled people, and research into barriers that prevent it, is clear: employment is not just a means to financial gain, it is intrinsically linked to many aspects of wellbeing. Research on the association between paid work and Quality of Life (QoL, a psychological concept that includes basic needs such as water, food, and shelter but also intangible factors such as productivity and belongingness) found that there was a strong relationship between success at work and feelings of general fulfilment, independence, belongingness, and self-efficacy in autistic individuals (Katz, Dejak, \& Gal, 2015). Further, daily participation in society through employment can also lead to social inclusion for people with disabilities (Gannon \& Nolan, 2007).

One way to support people with learning disabilities into the workplace is via supported employment schemes (Wehman, 1988). These schemes are tailored to the individual and include personalised, consistent support from dedicated job coaches. Research 
has shown that learning disabled individuals were four times more likely to find paid employment after undergoing a supported work internship than those who had not (Migliore, Timmons, Butterworth, \& Lugas, 2012). For example, a UK-based study showed that a supported employment scheme developed by the National Autistic Society resulted in favourable outcomes such as higher rates of employment for participants, more hours worked per week, and higher wages (Mawhood \& Howlin, 1999). The reliable and consistent professional support from job coaches, managers, and co-workers appears to be a major factor contributing to the success of supported work internship schemes (Renty \& Roeyers, 2006).

One such supported internship scheme is Project SEARCH. Founded in Cincinnati, Ohio in 1997 by Erin Riehle and Suzie Rutkowski, Project SEARCH is an individualised internship programme for learning disabled individuals that includes on-the-job support, a sampling of different work sites through regular rotation, and didactic classroom training to teach participants work-related skills (Rutkowski, Daston, VanKuiken \& Riehle, 2006). Project SEARCH has been active in the UK since 2010 and now operates in several work sites in and around the UK, allowing participants the benefit of a full-time nine-month programme to prepare them for paid employment. Research has begun to explore the efficacy of the programme and has found that this particular supported work internship model lead to successful employment outcomes for participants in terms of employment status, hours worked per week, and hourly wage (Wehman et al., 2012). A randomised control trial found that autistic participants who received Project SEARCH training in addition to the usual school-based autism supports did better on long-term measures of employment outcomes, specifically hours worked per week and hourly wage, than a control group who only received autism supports (Wehman et al., 2014). Likewise, it has been shown that, among 45 autistic adults in supported employment, the 25 who had received prior Project SEARCH training 
required fewer hours of intervention on the job than the 20 who had not undergone the Project SEARCH programme (Schall et al., 2015). Indeed an evaluation of the employment outcomes of 350 Project SEARCH graduates across 17 UK sites found a 50\% employment rate among former participants in the programme (Kaehne, 2016) - greater than the national average for this population. Recent reports from Project SEARCH in the UK cite an even more impressive statistic of $66 \%$ employment for participants at the end of the programme (DFN Project Search, 2019).

Despite these positive indicators, to our knowledge no research has examined the lived experiences and views of those who participated in the scheme. Indeed this is common in disability literature more generally, where the voices of learning disabled young people are rarely included (Clavering \& McLaughlin, 2010). Further, the existing research evaluating supported employment programmes has rarely taken the views of supervisors or job coaches into account, resulting in limited understanding of employer needs and any challenges encountered (Nicholas, Attridge, Zwaigenbaum, \& Clark, 2015). One recent study offered preliminary insight into these groups, interviewing three Project SEARCH staff and two coworkers at a jobsite in the USA (Almalki, 2019). Participants talked of a supportive environment, and held positive attitudes towards working with people with disabilities. What remains less clear, however, is how these attitudes map onto the experiences of the interns participating in this programme.

The current study addresses this gap by looking at the Project SEARCH model from the perspectives of its participants: both interns who underwent the scheme and the job coaches who worked with them throughout the programme. First, this will establish whether the quantitative outcome metrics seen in the previous research cited above (e.g. employment rates, hours worked) are consistent with the first hand experiences of those involved in the programme. Second, the findings will explore factors that participants feel contribute to the 
success of the programme, and aspects of the scheme that could be improved in order to lead to more favourable experiences and outcomes for participants in the future. We took a descriptive exploratory approach, in order to avoid imposing researcher bias that may arise when viewing data from those with intellectual impairment through the lens of neurotypical researchers. Further, the voices of those with intellectual impairment have rarely been taken into account when considering outcomes of supported employment schemes. As such, the present research represents a novel approach to this issue, and therefore required an exploratory approach.

\section{Methods}

\section{Programme Overview}

Project SEARCH is a supported work internship model that runs for approximately nine months. Participants in the programme are recruited through a competitive application process and are usually in their late teens or early twenties, and are often in their final year of secondary school. Criteria for entry always include a diagnosed significant learning or developmental condition, and participants are required to have fully independent self care skills, basic and effective communication skills (either verbal or using assisted technology), appropriate behaviour in the work place, the ability to take direction and change behaviour when necessary, and a desire to achieve competitive employment (Wehman et al., 2017). The model places interns in three rotations of 10-12 weeks each at three different job sites throughout the year, with social skills, communication skills, and job skills training taking place in an interactive classroom setting prior to their first rotation and at various points throughout their participation in the programme. Support is given to the interns through a classroom teacher, job coaches, co-workers, peers, and supervisors. The objective of the 
programme is for participants to achieve competitive employment at the conclusion of the programme.

\section{Participants}

The present study involved seven interns (aged 17-24 years, five male, two female) enrolled in the Project SEARCH programme from September 2017 to June 2018 and three job coaches (one male, two female), who worked alongside them. One of the job coaches had been job coaching for 20 years and had been working with Project SEARCH for several years, while the other two had joined the project at the start of the academic year and had previous experience working in mainstream schools with children without disabilities. The interns worked for a range of employers around Greater London and all had a diagnosed learning or developmental condition, including Down Syndrome, Specific Language Impairment (SLI), impaired vision in addition to intellectual impairment, and autism. In the interest of confidentiality, more specific information about the participants' diagnoses or demographics cannot be given. All of the interns had been participating in Project SEARCH for approximately eight months at the point at which the interviews were conducted, and the job coaches had been working with them throughout that period.

Recruitment was conducted via Project SEARCH coordinators at the sites in question who distributed information sheets to potential participants. A total of 12 participants were enrolled on the Project SEARCH programme at the sites in question. Of these, eight were deemed able to give informed consent by job coaches and were invited to take part in the study. Seven agreed to take part and signed consent forms prior to their participation in the study.

\section{Procedure}


Two separate interview schedules, one for the interns and the other for the job coaches, were developed to guide the one-on-one interviews. Questions for interns covered background information (e.g. age, and family background) views about the Project SEARCH internship and thoughts on work and future employment opportunities. For job coaches the interview included questions on prior experience, training and support at Project SEARCH, challenging or rewarding aspects of the role, feedback on the programme, and views on their own development, and the development of the interns throughout the scheme.

One-on-one interviews, conducted in person and lasting 10-20 minutes each, were held with each intern. Three interns chose to have a peer or job coach present. The job coaches were interviewed by telephone or in person, and interviews lasted approximately 30 minutes. Differences in interns' communication abilities were taken into account when conducting the intern interviews. In two cases, the interviewees had their Project SEARCH trainers present, as it helped them to have a known person in the room to assist with communication and understanding the questions. The interviewers also modified questions when necessary and presented written questions to interviewees who had auditory processing difficulties. The researchers used thematic analysis to process the data collected through the semi-structured interviews (Braun \& Clarke, 2006). Audio recordings of each interview were transcribed verbatim by the researchers then analysed independently without any pre-existing themes or preconceptions. In keeping with the exploratory nature of this study, an inductive approach was used to identify themes in the data. Two researchers (AMR and KY) examined the other's recorded interviews and verbatim transcripts to confirm veracity and accuracy. They then met and thematically coded these transcripts before exchanging coded transcripts to compare and align themes and sub-themes. Following discussion and further review, they established the final themes and sub-themes. All authors approached the analysis and discussions from the perspective of researchers who do not identify as learning disabled. 
Great care was taken, however, to analyse the data without preconceptions, and to avoid imposing our own interpretations (see limitation section below for more detail on this).

Ethics approval was granted by the UCL Institute of Education research ethics committee. Careful consideration was given to the ethical issues and potential risks involved in working with participants with intellectual impairment and reduced verbal communication abilities. Specifically, great care was taken to ensure that all participants gave informed consent when taking part in the study, paying attention to the three components of valid consent: freedom from coercion, competence, and disclosure of information (Goldsmith \& Skirton, 2015). To ensure no coercion was involved, interns were recruited via Project SEARCH staff who knew them personally and were able to identify suitable participants.

\section{Results}

Themes and subthemes that emerged from interviews with the interns and job coaches are presented in Figure 1. A comprehensive list of example quotes can be found in the Supplementary Materials. As there was a great deal of overlap in themes from the two groups, all are reported together. Similarities and differences between the groups are noted within the text.

Overall, the participants highlighted both enablers and barriers. Within the former, interns and job coaches spoke of a meaningful experience for all involved, positive selfdevelopment and renewed ambitions for the future. These were facilitated by a strong support network that the interns enjoyed within - and beyond - the Project SEARCH scheme. Barriers encountered along the way included interns' difficulties with social interaction and communication, and issues related to the relationship with their managers, for example lack of support or an underestimation of their abilities. Job coaches found the vast diversity within the group of interns challenging when devising supports. 
--- Figure 1 about here ---

\section{A Meaningful Experience}

The interns and job coaches spoke positively about the Project SEARCH programme. Interns showed a high level of pride: 'I'm really proud' (I1), and enthusiasm about being involved: 'I feel great! I like this!' (I2). This positivity tended to centre on three main areas. First, interns talked about the social benefits of the scheme such as working as part of a team: 'I am working in a team, team worker. I enjoyed it' (I5), and making friends: 'I am happy with my friends' (I6). Second, interns spoke of enjoying the independence afforded to them at their jobs: 'One time she let me do everything by myself' (I4) and third, how enjoyable the process of working was: 'It's fun to have jobs' (I2).

Job coaches echoed these positive sentiments, remarking on the high level of motivation seen in the interns:

'To see each of those young people grab the opportunity, which is joyous, I have to say it is absolutely joyous and see that they grab it because they really, really want it, ... and see them emerge as kind of ultimately self-sufficient adults who are exercising their own choices and developing their own careers and subsequently their lives. I think it is just remarkable.' (JC1).

The social advantages were also observed by the coaches, and they reflected on how interns formed connections with those around them: 'They've grown a lot in the social sense... ...they all used to come for lunch in the restaurant but now a lot of them are having lunch in their own departments' (JC2). This demonstrated a move from socialising solely with other interns or Job Coaches to spending break times with colleagues outside of the Project SEARCH team. 
One additional way in which job coaches felt that the scheme was meaningful was that it created positive role models for others with learning disabilities: 'Someone with a disability seeing someone else being a [specific role] could be like 'oh look, I could do that too' (JC2). Similarly, they remarked on how interns were ambassadors more widely: 'A lot of people notice them, but usually for positive things, they bring that caring, attached role which is really good' (JC2). As such, they were raising awareness within the general public of the positive contributions those with learning disabilities make within the workplace.

Job coaches also highlighted mutual benefits - to both interns and their employers of the work experience afforded by the Project SEARCH scheme. For interns, it helps build an employment record: 'We have a wealth of history that shows people aren't very successful in employment because they don't get enough of it' (JC1). For employers, it raises awareness of the meaningful contributions that those with disabilities make in the workplace: 'It's [the scheme] seldom about what the individual might be able to do for the employer. It's very one-sided. It's not often presented as a win-win as an employment relationship has to be' (JC1). Coaches felt that this challenged the assumption that such internships are solely about helping the individual with the disability, but instead offer reciprocal benefits.

\section{Self-Development}

One of the main benefits of the scheme, raised by both groups of participants, was the development of interns' skills across the programme: 'I improve myself' (I4). Some of these were work related, such as technical aspects of the role the intern was undertaking, and many were more general 'soft' skills such as communication: 'Talking [to] more people, it helps improve my communication' (I5), and life skills: 'It serve me like life skills; how to manage your money, how to do work, how to behave in a work environment and how to follow fire safety procedures' (I4). 
This self-development appeared to have a beneficial impact on interns' confidence, something that was noted by both interns: 'This is a good internship and it gains you confidence' (I2), and job coaches: 'It's about that confidence, the belief in themselves, selfworth, that's the biggest transformation' (JC1)). Job coaches also remarked that another benefit of the scheme was their own positive development through the process: 'My confidence has definitely grown doing this job, 100\%' (JC2).

\section{A Strong Support Network}

It was clear from interviews with both groups that the interns enjoyed a high level of support both within and beyond the Project SEARCH scheme. Interns spoke of education providers who had helped them apply for the internship: 'A teacher assistant of mine at [school] showed me how you can apply for it and I came straight from there' (I4), and a supportive home environment: 'My mum, my dad, my brother' [help me at home] (I2). Interns also made numerous references to the guidance offered to them by supervisors/managers and Project SEARCH teachers and job coaches: 'If there is a problem, I speak to my manager, my supervisor or my work colleagues or teachers or job coach. That's it' (I5). While the vast majority of comments were positive, it is important to reflect that there were also interns who felt that additional support would be welcome: '[I would like] More help... To get more into the job and to know the rules, what they do in a job' (I2).

Job coaches highlighted the value of family involvement and its 'critical' contribution to the interns' success, but also recognised the crucial role that they themselves play:

'It's just about keeping them motivated and keeping them on track, and helping them through the difficult stages of working, making sure they're not put off by what goes wrong...Like anything can be overcome so just being their support system is really, really important' (JC2). 
In some cases, the support involved advising those working alongside the interns: 'So helping their colleagues understand how to work with these sorts of situations [social expectations] and not to be judgemental about it' (JC1).

This support did not end with the programme: 'There's still a few looking for jobs, so if I have time I call them in here to apply, and then I went for an interview with someone last week so I still do that part of the role' (JC2). It was also impressive to see that the job coaches were continuing to support previous Project SEARCH participants, long after they had completed the internship.

\section{Ambitions for the Future}

Interns expressed clear aspirations and goals for the future, most commonly that they were keen to obtain a paid job at the conclusion of the Project SEARCH programme: 'I'm going to graduate, I'm going to get my own job' (I5). In a number of cases, the jobs that interns were aiming for were directly related to their work placements during the Project SEARCH scheme. They also recognised the important role that Project SEARCH played in helping them work towards their employment goals:

'You're going to have to enter [work] alone, and that may give you a shock and that may make you a bit scared and that may make you a bit nervous about what you're actually doing, but in this internship you get full support from the job coaches, full support from the teachers, full support from the managers, and if you don't get the full support, the Project Search company makes sure that you get the full support. Because this full support is to help you get a job' (I1).

Job coaches reflected on how these ambitions had grown as a result of the programme and were often at odds with the prior expectations held by those who knew them: 'These 
young people probably until that point of joining a PS programme probably have very low aspirations and expectations of themselves, as do generally their families and those around them,' (JC1). They were sensitive to the fact that for families, accepting these higher expectations could be challenging: 'I think it's a huge ask for parents who haven't really been thinking about employment, it's not really been on the agenda. Suddenly PS comes along it's a real leap of faith, we are asking them to take' (JC1).

While job coaches were supportive of interns' ambitions, they were also candid about the barriers that needed to be overcome to achieve them:

'Our biggest problem, is that having realised that they kind of want to start to build their lives beyond work or through work and beyond work, and therein lies a problem that we face increasingly... there's very little support around them to help them build lives'. (JC1).

They reported many rejections in the interns' paths to obtain subsequent employment:

'We've had a few weeks when we've got so many job rejections or departments not being very helpful' (JC2), and commented on how competitive employment recruitment processes do not offer a true reflection of interns' abilities: 'I find it's quite unfair, because we know how they work, but an interview won't show them that, as they're so nervous' (JC2). Coaches added:

'It seems to be that securing the job for many people, particularly families, is the end result. That's it, we've done it. But we have to say, no, no, no it's going to open up a whole can of worms... Getting a job is merely the start, not the end of the process' (JC1).

The job coaches stressed that, despite the inherent value placed on obtaining a subsequent job placement, it should not be considered the final point in the employment journey. 


\section{Challenges Along the Way}

Despite the positive sentiments above, the Project SEARCH programme was not without its challenges for the interns. Some spoke of difficulties with social interaction: 'They [customers] can be rude. They are shouting, they put pressure on me' (I5), while others referred to issues around communication: 'You can't understand what they want, no they say they want this no they want this, no they want that, so it's kind of hard to understand them' (I1). Job coaches agreed that communication was an issue: 'Maybe some of them, their communication isn't great... The biggest [barrier] is about communication, really' (JC3). Indeed, as well as proving a challenge to interns, communication was perceived to be the greatest issue that job coaches themselves encountered during the programme: 'I think [the hardest thing in the role] is just the communication thing, to be honest. It's about not being able to say if and when they need help' (JC3).

Some challenges centred on the relationship between interns and their managers. Job coaches remarked that they felt the support offered to the interns by their placement managers/colleagues was in some cases insufficient: 'Possibly they don't have quite enough time to provide the support they want' (JC1). They speculated that this might be due to a lack of understanding about what level of input the interns require in order to thrive in the workplace. One explained: 'The novelty [of an intern] wears off after a week or two, and so once they actually realise the time that they need to invest to get like amazing results it kind of wears off after a bit...' (JC3). In other cases, opposite misconceptions were seen, with colleagues or members of the public holding stereotypes that meant they underestimated interns' abilities: 'I think the hardest bit is peoples' opinions and how, like, judgemental people can be and how they perceive disabilities and learning difficulties' (JC3).

Interestingly, job coaches highlighted intern diversity as a barrier to providing effective support: 'Probably how different all the interns are. If they all have the same 
problem, you can't deal with them all in the same way. It's very individualised, which can be a challenge' (JC2). Coaches understood the need to move away from group stereotypes to focus on individual abilities when offering support.

\section{Discussion}

The present study explored the lived experience of job coaches and interns involved in a UK-based vocational training programme with Project SEARCH in 2017-2018. All participants felt that the scheme was a meaningful experience that led to self-development, both for interns themselves and those who worked alongside them. This is in line with the recent study by Almalki (2019) where Project SEARCH staff also remarked that they observed interns' growth and development across the programme. Those we spoke to talked about a growing sense of self-confidence and independence with the progression of the course, practical skill acquisition, teamwork, social benefits and feelings of well being resulting from the internship. This success appeared to result in raised ambitions for the future, with interns now motivated to pursue subsequent employment goals after the conclusion of the scheme. The ambitions that the interns had for themselves after undergoing the Project SEARCH programme also seemed to surpass the expectations that others had set for them before their involvement - in line with findings from previous research showing generally low employment expectations held by family members of disabled individuals (Beyer, Meek \& Davies, 2016).

It is encouraging that the lived experiences map onto the more quantitative outcomes that have been used in previous research to measure the value of the Project SEARCH model (e.g. subsequent employment status, hours worked and support needed), (Wehman et al., 2012; Schall et al. 2015). Our research established that these statistics were accompanied by positive experiences of those involved. The importance of eliciting the voices of the young 
people directly involved in Project SEARCH is underlined by the fact that such individuals are too often excluded from the research process (Clavering \& McLaughlin, 2010) in favour of using caregiver reports as a proxy for their opinions. For example, one study on the views of young people with Down's Syndrome showed that their ideas about their own well-being did not necessarily match up with societal expectations of what constitutes success and happiness, with most participants expressing overall satisfaction and a positive outlook on their lives despite not conforming to traditional expectations of success (Scott, Foley, Bourke, Leonard, \& Girdler, 2014). This reiterates the need for researchers to speak directly to participants - particularly those with learning or developmental conditions.

When considering the specific benefits derived from the Project SEARCH scheme, interns and job coaches we spoke to felt that one of the key aspects was an increase in interns' self-confidence. This is crucial, given the link between perceived self-efficacy and employment success. In the general population, research has highlighted positive correlations between self-efficacy and workplace performance, job satisfaction, health and wellbeing (Judge \& Bono, 2001). Moreover, our findings are in keeping with research showing that those on the autistic spectrum (Remington \& Pellicano, 2018) and those with other disabilities such as intellectual impairment (Nota, Ginevra, \& Carrieri, 2010) are populations at risk of having lower workplace self-efficacy due to negative prior experiences of job seeking/maintaining or the lack of any job-related experiences, which may be further exacerbating the already low employment rates.

Alongside the positive impact on the interns, it was interesting to see the mutual benefits of the scheme for those who worked alongside them. Job coaches remarked on their own personal development and also how interns served as role models for others with disabilities, or for managers and colleagues who previously held misconceptions about the 
contributions that those with learning disabilities can make in the workplace. Numerous studies have revealed negative stereotypes held by employers (e.g. that people with disabilities need many modifications, have more time absent from work and struggle socially) and conclude that potential employers need more practical information and experience in order to combat these concerns and prejudices (Burke, Beyzak, Fraser, Pete, Ditchman \& Chan, 2013). Indeed, the majority of employers who do hire disabled people are happy with their contribution (Burke et al., 2013; Mawhood \& Howlin 1999) and recognise the benefits of diverse skills.

The present study also begins to give insight into what might contribute to the successful outcomes achieved by this particular group of young people. Interns spoke often of the strong support network they had, which included their family and former education providers. It was clear that these supporters had helped them identify and apply for the Project SEARCH programme. Indeed family support has been shown to benefit employment outcomes (Nicholas, Mitchell, Dudley, \& Clarke, 2017) via emotional support, planning and practical facilitation, while a paucity of family support predicts job failure (Walsh, Lydon \& Healy, 2014).

As well as the assistance that had helped them achieve a place on the Project SEARCH internship, the importance of on-going support from job coaches, teachers and colleagues throughout the programme was clear. Specifically our results echo the welldocumented need for an individualised approach for each intern seen in previous research (Chen, Leader, Sung \& Leahy, 2015). The job coaches in the present study were very aware that each person must be treated as an individual, and that careful job-to-skills matching is crucial to employment success (Beyer, Meek \& Davies, 2016). 
Despite overwhelmingly positive sentiments expressed by all we spoke to, there were also a number of challenges raised. Interns remarked on encountering some social and communication difficulties with customers - an issue that was echoed by the job coaches in our study and also those in previous research (Almalki, 2019). The job coaches we spoke to added that other challenges related to the relationship between interns and their managers. Specifically, that in some cases managers underestimated interns' abilities, or offered an insufficient level of support to them. This is in contrast with the work by Almalki (2019) where co-workers believed in the interns' abilities and that they should be given many opportunities. In that study, however, only two co-workers were interviewed and, by definition, those who are willing to be involved in such a study may be the most supportive of the internship. It would be interesting to explore the views of a wider group of people working alongside the interns.

One of the most frequently mentioned concerns in our study centred on interns' next steps at the conclusion of the Project SEARCH programme: as the disabled and autistic young people find work and develop their own lives without the intense support offered by the programme. Though job coaches were happy to see interns' new employment goals and future ambitions, they were also worried about the barriers that must be overcome to make these a reality. Job coaches highlighted the number of rejections they had already witnessed during the process of helping interns seek subsequent employment, and remarked that the competitive recruitment process was not generally conducive to showcasing the interns' abilities. Although a body of evidence now illustrates the efficacy and undeniable positives of vocational skills training and supported internships (Walsh et al., 2014), it is less clear how well internship graduates cope in the competitive work environment with the absence of ongoing help. Our findings suggest the need for support structures (albeit at a reduced level of input) that could be put in place after the end of the Project SEARCH placements to capitalise 
on the progress made by interns through the scheme, and further promote positive employment outcomes. This is consistent with past research that has shown on-going support in the work environment to be a contributing factor to success (Hendricks, 2010; Walsh et al., 2014).

\section{Limitations}

The current study involved a small number of individuals, from one location, and therefore the extent to which the findings can be generalised may be limited. In addition, those who participated were the interns who were able to give informed consent. This meant that the less able members of the programme were not included in our research. Further, the views of the managers working with the Project SEARCH interns were not included here. Future research should seek to elicit these employer views, and include a broader sample of interns. It will also be important to compare the views of our participants with those enrolled on other similar internship programmes. In this way, we can begin to establish the relative successes of various pathways to employment for young people with learning disabilities.

Methodological issues inherent in qualitative analyses should also be noted. It is possible that when interviewing those with limited verbal communication abilities, researcher bias may become introduced. Validity may be affected by the vulnerability of people with intellectual impairment through acquiescence to authority, lack of understanding of language or vocabulary, difficulty in concentration or the effects of poor memory (Milne and Bull, 2001). To guard against these, we used a flexible approach with validation and screening of responses (especially to yes/no questions), were aware of acquiescence, attempted to use open-ended questions, maintained an awareness of memory load and capability, and were aware of reflexive interviewing whereby the researcher does not implicate their own preconceptions or impose their own interpretations (Bailey et al 2014). Interviews were also 
planned using Yardley's (2000) sensitivity to context and by keeping uppermost in mind the existing socio-cultural environment of this scheme.

\section{Conclusion}

In conclusion, the current study marks the first step towards better understanding the multiple perspectives of those involved in the Project SEARCH internship programme. The findings highlight both successes and the factors that might contribute to them, and areas that can be developed to further improve outcomes. This is vital given the employment gap that individuals with additional needs are facing in the UK. Supported work internships, particularly the Project SEARCH model, have been empirically shown to be effective in helping with transition into employment, but the quantitative measures used thus far to track success (hours worked per week, employment status, hourly wage, and support needs) give an incomplete picture of scheme outcomes. Representing the first hand voices of participants is necessary to understand what positive outcomes look like for individuals with learning disabilities - through their own eyes.

In addition, what remains unknown is how successful are the subsequent jobs obtained by Project SEARCH graduates. Given the sentiments of the job coaches in the current study who underlined the need to consider employment as the first step in an ongoing journey, this should be further explored This is particularly important as those on the autistic spectrum or with disabilities often experience malemployment (jobs inconsistent with their skills/abilities) or underemployment (jobs for which they are overqualified) (Baldwin, Costley \& Warren, 2014).

Lastly, the views and preferences of participants presented here are especially relevant as a starting point for more participatory research, through which individuals with additional needs would be given the opportunity to become fully involved in the development of further 
adult support programmes to maximise employment outcomes for those with learning disabilities.

Financial Support: This research received no specific grant from any funding agency, commercial, or not-for-profit sectors.

Conflicts of Interest: None 


\section{References}

Almalki, S. (2019). A qualitative study of supported employment practices in Project SEARCH, International Journal of Developmental Disabilities, Advance Online Publication. DOI: $\underline{10.1080 / 20473869.2019 .1627793}$

Austin, R. \& Pisano, G. (2017). Neurodiversity as a competitive advantage. Harvard Business Review, 95(3), 96-103.

Bailey, S., Boddy, K., Briscoe, S., \&Morris, C. (2015). Involving disabled children and young people as partners in research: a systematic review. Child: Care, Health and Development. 41(4), 505-514.

Baldwin, S., Costley, D., \& Warren, A. (2014). Employment activities and experiences of adults with high-functioning autism and Asperger's Disorder. Journal of Autism and Developmental Disorders, 44(10), 2440-2449.

Beyer, S., Meek, A., \& Davies, A. (2016). Supported work experience and its impact on young people with intellectual disabilities, their families and employers. Advances in Mental Health and Intellectual Disabilities, (10)3, 207-220.

Braun, V., \& Clarke, V. (2006). Using thematic analysis in psychology. Qualitative Research in Psychology 3(2) 77-101.

Burke, I., Beyzak, J., Fraser, R., Pete, J., Ditchman, N., \& Chan, F. (2013). Employers Attitudes Towards Hiring and Retaining People with Disabilities: A Review of the Literature. Australian Journal of Rehabilitation Counselling, 19(1), 21-28.

Chen, J.L., Leader, G, \& Sung, C. \& Leahy (2015). Trends in Employment for Individuals with Autism Spectrum Disorder: a Review of the Research Literature. Review Journal of Autism and Developmental Disorders 2(2), 115-127.

Clavering, E.K., \& McLaughlin, J. (2010). Children's participation in health research: From objects to agents? Child: Care, Health, and Development, 36(5), 604-611.

DFN Project SEARCH (2019). Retrieved from https://www.dfnprojectsearch.org/

Gannon, B. \& Nolan, B. (2007). The impact of disability transitions on social inclusion. Social Science \& Medicine, 64(7), 1425-1437.

Goldsmith, L., \& Skirton, H. (2015). Research involving people with a learning disability methodological challenges and ethical considerations. Journal of Research in Nursing, 20(6), $435-446$.

Hendricks, D, (2010). Employment and adults with autism spectrum disorders: challenges and strategies for success. Journal of Vocational Rehabilitation 32 (2), 125-134. 
Judge, T., \& Bono, J. (2001). Relationship of core self-evaluation traits-self-esteem, generalized self-efficacy, locus of control, and emotional stability - with job satisfaction and job performance: a meta-analysis. Journal of Applied Psychology, 86(1), 80-92.

Kaehne, A. (2016). Project Search UK: Evaluating its employment outcomes. Journal of Applied Research in Intellectual Disabilities, 29(6), 519-530.

Katz, N., Dejak, I., \& Gal, E. (2015). Work performance evaluation and QoL of adults with high functioning autism spectrum disorders (HFASD). Work, 51(4), 1-16.

doi: 10.3233/WOR-152001

Mawhood, L. \& Howlin, P. (1999). The outcome of a supported employment scheme for high functioning adults with autism or Asperger syndrome. Autism 3(3).

Migliore, A., Timmons, J., Butterworth, J., \& Lugas, J. (2012). Predictors of employment and Postsecondary Education of Youth with Autism. Rehabilitation Counseling Bulletin 55(3). 176-184.

Milne, R., \& Bull, R. (2001). Interviewing witnesses with Learning disabilities for Legal Purposes. Psychology, Crime and Law, 5, 81-100.

Mottron, L. (2011). Changing perceptions: The power of autism. Nature, 479(7371), 33-35.

Nicholas, D.B., Attridge, M., Zwaigenbaum, L. \& Clarke, M. (2015). Vocational support approaches in autism spectrum disorder: A synthesis review of the literature. Autism 19(2),35-245.

Nicholas, D.B., Mitchell, W., Dudley, C. \& Clarke, M. (2017). An Ecosystem Approach to Employment and Autism Spectrum Disorder. Journal of Autism \& Developmental Disorders 48(1), 264-275.

Nota, L., Ginevra, M.C., \& Carrieri, L. (2010). Career interests and self-efficacy beliefs among young adults with an intellectual disability. Journal of Policy and Practice in Intellectual Disabilities, 7(4). 250-260.

Remington, A., \& Pellicano, E. (2018) 'Sometimes you just need someone to take a chance on you' An Internship Programme for Autistic Graduates at Deutsche Bank, UK. Journal of Management and Organization.25(4), 516-534.

Renty J.O. \& Roeyers H. (2006). Quality of life in high-functioning adults with autism spectrum disorder: The predictive value of disability and support characteristics. Autism, $10(5), 511-524$.

Rutkowski, S., Daston, M., VanKuiken, D., Reihle, E. (2006). Project SEARCH: A demandside model of high school transition. Journal of Vocational Rehabilitation, 25(2) 85-96. 
Schall, C.M., Wehman, P. et al. (2015). Employment interventions for individuals with ASD: The relative efficacy of supported employment with or without prior project SEARCH training. Journal of Autism and Developmental Disorders, 45(12), 3990-4001.

Scott, M., Foley, K.R., Bourke, J., Leonard, H., \& Girdler, S. (2014). 'I have a good life': the meaning of well-being from the perspective of young adults with Down Syndrome. Disability and Rehabilitation, 36(15), 1290-1298.

UK Parliament Report (2018). People with disabilities in employment. London, United Kingdom: House of Commons Library.

Walsh, L., Lydon, S., \& Healy, O. (2014). Employment and Vocational Skills Among Individuals with Autism Spectrum Disorder: Predictors, Impact and Interventions. Review Journal of Autism and Developmental Disorders 1(4), 266-275.

Wehman, P. (1988). Supported Employment: Toward Equal Employment Opportunity for Persons with Severe Disabilities. Mental Retardation, 26(6). 357-61.

Wehman, P., Schall, C., McDonough, J., Molinelli, A., Riehle, E., Ham, W., \&Thiss, W. (2012). Project SEARCH for Youth with Autism Spectrum disorders: Increasing Competitive Employment On Transition From High School. Journal of Positive Behaviour Interventions 15(3).

Wehman, P., Schall, C.M., McDonough, J., Kregel, J., Brooke, V., Molinelli, A., Ham, W., Graham, C., Riehle, J.E., Collins, H.T., \& Thiss, W. (2014). Competitive Employment for Youth with Autism Spectrum Disorders: Early Results from a Randomized Clinical Trial. Journal of Autism and Developmental Disorders, 44,487-500.

Wehman, P., Schall, C.M. McDonough, J., Graham, C., Brooke, V., Riehle, J.E., Brooke, A., Ham, W., Lau, S., Allen, J., Avellone, L. (2017). Effects of an employer-based intervention on employment outcomes for youth with significant support needs due to autism. Autism,21(3), 276-290.

Yardley, L. (2012). Dilemmas in qualitative health research. Psychology and Health (15)2, 215-228. 
Table 1. Themes and subthemes from intern and job coach interviews, with illustrative quotes

\begin{tabular}{|c|c|c|c|}
\hline Themes & Sub-themes & Intern Quotes & Job Coach Quotes \\
\hline \multirow[t]{4}{*}{$\begin{array}{l}\text { 1. A Meaningful } \\
\text { Experience }\end{array}$} & $\begin{array}{l}\text { a) Social factors, } \\
\text { teamwork, and } \\
\text { friendship }\end{array}$ & $\begin{array}{l}\text { "Included in the team, } \\
\text { in the training } \\
\text { classroom, I enjoyed } \\
\text { it. I'm part of that } \\
\text { team, yes." (I5) }\end{array}$ & $\begin{array}{l}\text { "They've grown a lot in } \\
\text { the social sense... } \\
\text {..they all used to come } \\
\text { for lunch in the } \\
\text { restaurant but now a lot } \\
\text { of them are having } \\
\text { lunch in their own } \\
\text { departments". (JC2) }\end{array}$ \\
\hline & b) Independence & $\begin{array}{l}\text { "Yes and one time she } \\
\text { let me do everything } \\
\text { by myself." (I4) } \\
\text { "I want to be } \\
\text { independent. I'm } \\
\text { working towards } \\
\text { that." (I5) }\end{array}$ & $\begin{array}{l}\text { "[To] see them emerge } \\
\text { as kind of ultimately } \\
\text { self-sufficient adults } \\
\text { who are exercising their } \\
\text { own choices and } \\
\text { developing their own } \\
\text { careers and } \\
\text { subsequently their } \\
\text { lives...I think it is just } \\
\text { remarkable." (JC1) }\end{array}$ \\
\hline & $\begin{array}{l}\text { c) Ambassadors } \\
\text { (for public and } \\
\text { others with } \\
\text { disabilities) }\end{array}$ & & $\begin{array}{l}\text { "Someone with a } \\
\text { disability seeing } \\
\text { someone else being a } \\
\text { water host on their ward } \\
\text { could like, 'Oh look, I } \\
\text { could do that too."" } \\
\text { (JC2) } \\
\text { "It's about } \\
\text { expectations...employe } \\
\text { rs don't get the } \\
\text { opportunity to learn and } \\
\text { work alongside people } \\
\text { with learning } \\
\text { disabilities and } \\
\text { autism..." (JC1) }\end{array}$ \\
\hline & $\begin{array}{l}\text { d) The mutual } \\
\text { value of work } \\
\text { experience }\end{array}$ & & $\begin{array}{l}\text { We have a wealth of } \\
\text { history that shows } \\
\text { people aren't very } \\
\text { successful in } \\
\text { employment because } \\
\text { they don't get enough } \\
\text { of it" (JC1). } \\
\text { "One of my criticisms } \\
\text { for the secondary } \\
\text { education system is that } \\
\text { because it is segregated, } \\
\text { young people with } \\
\text { learning disabilities or }\end{array}$ \\
\hline
\end{tabular}




\begin{tabular}{|c|c|c|c|}
\hline & & & $\begin{array}{l}\text { autism are not learning } \\
\text { alongside people who } \\
\text { may ultimately become } \\
\text { their employer." (JC1) }\end{array}$ \\
\hline \multirow[t]{3}{*}{$\begin{array}{ll}\text { 2. } & \text { Self- } \\
& \text { Development }\end{array}$} & $\begin{array}{l}\text { a) Improved work } \\
\text { and life skills }\end{array}$ & $\begin{array}{l}\text { "It serve me like life } \\
\text { skills: how to manage } \\
\text { your money, how to } \\
\text { do work, how to } \\
\text { behave in a work } \\
\text { environment, and how } \\
\text { to follow fire safety } \\
\text { procedures." (I4) }\end{array}$ & $\begin{array}{l}\text { "... To see that change } \\
\text { in } 9 \text { months, becoming } \\
\text { very aspirational, } \\
\text { beyond their wildest } \\
\text { dreams, ...it's a } \\
\text { privilege to be } \\
\text { connected to that". } \\
\text { (JC1) }\end{array}$ \\
\hline & b) Communication & $\begin{array}{l}\text { "I improve myself, my } \\
\text { communication } \\
\text { skills... Talking more } \\
\text { people, it helps to } \\
\text { improve my } \\
\text { communication." (I5) }\end{array}$ & $\begin{array}{l}\text { "At the beginning I had } \\
\text { to encourage them to } \\
\text { speak louder, speak } \\
\text { slower, but now they're } \\
\text { very confident which is } \\
\text { so, so good to see." } \\
\text { (JC2) }\end{array}$ \\
\hline & $\begin{array}{l}\text { c) } \begin{array}{l}\text { Confidence } \\
\text { building }\end{array}\end{array}$ & $\begin{array}{l}\text { "This is a good } \\
\text { internship and it gains } \\
\text { you confidence." (I2) }\end{array}$ & $\begin{array}{l}\text { "It's about that } \\
\text { confidence, the belief in } \\
\text { themselves, self-worth, } \\
\text { that's the biggest } \\
\text { transformation." (JC1) }\end{array}$ \\
\hline \multirow[t]{3}{*}{$\begin{array}{l}\text { 3. Challenges } \\
\text { Along the } \\
\text { Way }\end{array}$} & $\begin{array}{l}\text { a) Social } \\
\text { interaction }\end{array}$ & $\begin{array}{l}\text { "They (customers) can } \\
\text { be rude. They are } \\
\text { shouting, they put } \\
\text { pressure on me" (I5). }\end{array}$ & \\
\hline & b) Communication & $\begin{array}{l}\text { "You can't understand } \\
\text { what they want, no } \\
\text { they say they want } \\
\text { this no they want this, } \\
\text { no they want that, so } \\
\text { it's kind of hard to } \\
\text { understand them" (I1). }\end{array}$ & $\begin{array}{l}\text { "Maybe some of them, } \\
\text { their communication } \\
\text { isn't great... The } \\
\text { biggest thing (barrier) I } \\
\text { think of all of it is about } \\
\text { communication, } \\
\text { really... the thing that } \\
\text { would probably make } \\
\text { our job a lot, lot easier } \\
\text { if the interns were able } \\
\text { to say what they needed } \\
\text { help with... it's about } \\
\text { not being able to say if } \\
\text { and when they need } \\
\text { help" (JC3). }\end{array}$ \\
\hline & $\begin{array}{l}\text { c) lack of manager } \\
\text { support }\end{array}$ & $\begin{array}{l}\text { Researcher: "Do you } \\
\text { think you have enough } \\
\text { help or would you like } \\
\text { more?" }\end{array}$ & $\begin{array}{l}\text { "Possibly they don't } \\
\text { have quite enough time } \\
\text { to provide the support } \\
\text { they want". (JC1) }\end{array}$ \\
\hline
\end{tabular}




\begin{tabular}{|c|c|c|c|}
\hline & & $\begin{array}{l}\text { I2: "More help." } \\
\text { Researcher: "You } \\
\text { would like more help. } \\
\text { In what way?" } \\
\text { I2: "To get more into } \\
\text { the job and to know } \\
\text { the rules, what they do } \\
\text { in a job." }\end{array}$ & \\
\hline & $\begin{array}{l}\text { d) Underestimation } \\
\text { of intern abilities }\end{array}$ & & $\begin{array}{l}\text { "In the café I showed a } \\
\text { video of him like frying } \\
\text { chips so then they were } \\
\text { like 'oh, he can actually } \\
\text { do more', so now he's } \\
\text { prepping salads". (JC2) } \\
\text { "If you treat them like } \\
\text { kids they won't respond } \\
\text { to you well so just be } \\
\text { patient and be like an } \\
\text { adult, and realise they } \\
\text { do understand if I'm } \\
\text { patient with them." } \\
\text { (JC2) }\end{array}$ \\
\hline & $\begin{array}{l}\text { e) The need for an } \\
\text { individual } \\
\text { approach }\end{array}$ & & $\begin{array}{l}\text { Researcher: "What do } \\
\text { you find challenging?" } \\
\text { Coach: "Probably how } \\
\text { different all the interns } \\
\text { are. If they all have the } \\
\text { same problem, you } \\
\text { can't deal with them all } \\
\text { in the same way. It's } \\
\text { very individualised, } \\
\text { which can be a } \\
\text { challenge". } \\
\text { "...This is very, very } \\
\text { individualised". (JC2) }\end{array}$ \\
\hline \multirow[t]{3}{*}{$\begin{array}{ll}\text { 4. } & \text { A Strong } \\
\text { Support } \\
\text { Network }\end{array}$} & a) At school & $\begin{array}{l}\text { "A teacher assistant of } \\
\text { mine showed me how } \\
\text { you can apply for it } \\
\text { and it came straight } \\
\text { from there." (I4) }\end{array}$ & \\
\hline & b) From family & $\begin{array}{l}\text { Researcher: "Who } \\
\text { helps you at home?" } \\
\text { "My mum, my dad, } \\
\text { my brother." (I2) }\end{array}$ & $\begin{array}{l}\text { "Every } 6 \text { weeks, there's } \\
\text { an employment - } \\
\text { planning meeting, } \\
\text { which is where the } \\
\text { parents come in" (JC2). }\end{array}$ \\
\hline & $\begin{array}{l}\text { c) From Project } \\
\text { SEARCH }\end{array}$ & $\begin{array}{l}\text { "Job coaches are } \\
\text { always there to help } \\
\text { you. If you have a }\end{array}$ & $\begin{array}{l}\text { Researcher: "What do } \\
\text { you think is the most } \\
\text { important thing about }\end{array}$ \\
\hline
\end{tabular}




\begin{tabular}{|c|c|c|c|}
\hline & & $\begin{array}{l}\text { problem, you go to } \\
\text { them." (I1) } \\
\text { Researcher: "Nothing } \\
\text { difficult, ah that's so } \\
\text { cool. So if you had a } \\
\text { problem or if you } \\
\text { found something } \\
\text { difficult, who would } \\
\text { you ask?" } \\
\text { Intern: "My teacher or } \\
\text { my job coach". (I7) }\end{array}$ & $\begin{array}{l}\text { your role?' Job Coach: } \\
\text { I think it's just } \\
\text { supporting the young } \\
\text { people, Without this, } \\
\text { most of them wouldn't } \\
\text { even think about } \\
\text { working or getting a } \\
\text { job... So I think it's just } \\
\text { about keeping them } \\
\text { motivated and keeping } \\
\text { them on track, and } \\
\text { helping them through } \\
\text { the difficult stages of } \\
\text { working, making sure } \\
\text { they're not put off by } \\
\text { what goes wrong...Like } \\
\text { anything can be } \\
\text { overcome so just being } \\
\text { their support system is } \\
\text { really, really } \\
\text { important." (JC2) }\end{array}$ \\
\hline \multirow[t]{3}{*}{$\begin{array}{l}\text { d) Ambitions for } \\
\text { the Future }\end{array}$} & $\begin{array}{l}\text { a) Keen for } \\
\text { subsequent } \\
\text { employment }\end{array}$ & $\begin{array}{l}\text { "My goal is to get a } \\
\text { job, get a paid job." } \\
\text { (I1) } \\
\text { "My goal is to get a } \\
\text { job" (I3). }\end{array}$ & $\begin{array}{l}\text { "I feel there is an end } \\
\text { goal and we're so } \\
\text { motivated to get them } \\
\text { to the end goal and get } \\
\text { a job, so this is really } \\
\text { good for me to have a } \\
\text { goal and do anything I } \\
\text { can to help them." } \\
\text { (JC2) }\end{array}$ \\
\hline & $\begin{array}{l}\text { b) Higher } \\
\text { expectations }\end{array}$ & & $\begin{array}{l}\text { "These young people } \\
\text { probably until that point } \\
\text { of joining a PS } \\
\text { programme probably } \\
\text { have very low } \\
\text { expectations of } \\
\text { themselves, as do } \\
\text { generally their families } \\
\text { and those around } \\
\text { them". (JC1) }\end{array}$ \\
\hline & $\begin{array}{l}\text { c) Barriers to } \\
\text { competitive } \\
\text { employment }\end{array}$ & & $\begin{array}{l}\text { The hardest thing, to be } \\
\text { honest, is employer- } \\
\text { engagement. I think that } \\
\text { part of the role is really } \\
\text { difficult because there } \\
\text { is a lot of rejection... we } \\
\text { are always trying to } \\
\text { break that barrier and to } \\
\text { be honest I think that's } \\
\text { the hardest thing about }\end{array}$ \\
\hline
\end{tabular}




\begin{tabular}{|l|l|l|}
\hline & & $\begin{array}{l}\text { it and it's the constant } \\
\text { rejection". (JC3) } \\
\text { "I find it quite unfair, } \\
\text { because we know how } \\
\text { they work, but an } \\
\text { interview won't show } \\
\text { them that, as they're so } \\
\text { nervous". (JC2) }\end{array}$ \\
\hline $\begin{array}{ll}\text { d) Ajourney } \\
\text { beyond } \\
\text { employment }\end{array}$ & $\begin{array}{l}\text { "It seems to be that } \\
\text { securing the job for } \\
\text { many people, } \\
\text { particularly families, is } \\
\text { the end result. That's it, } \\
\text { we've done it. But we } \\
\text { have to say, no, no, no } \\
\text { it's going to open up a } \\
\text { whole can of worms... } \\
\text { Getting a job is merely } \\
\text { the start, not the end of } \\
\text { the process". (JC1) }\end{array}$ \\
\hline
\end{tabular}

